\title{
Concomitant mitral valve repair and resynchronization therapy
}

\author{
S Borovic ${ }^{*}$, V Ristic, L Angelkov, Z Vukajlovic, P Dabic, B Djukanovic \\ From 23rd World Congress of the World Society of Cardio-Thoracic Surgeons \\ Split, Croatia. 12-15 September 2013
}

\section{Background}

Functional mitral regurgitation (MR) affects $90 \%$ of cardiac resynchronization therapy (CRT) candidates, with moderate-severe/severe MR being present in 35\%. The purpose was to assess the outcome of CRT candidates with severe MR undergoing concomitant mitral valve repair and resynchronization therapy.

\section{Methods}

A case series of 3 consecutive patients underwent concomitant mitral valve repair and resynchronization therapy between September 2011 and January 2012 at our institution. Prospectively recorded preoperative, intraoperative, and postoperative data were retrospectively screened for in-hospital mortality, adverse postoperative events and functional and echocardiographic changes. Patients were reevaluated at 6 and 12 months.

\section{Results}

There was no in-hospital mortality and major adverse postoperative events. End-systolic LV volumes decreased by $>20 \%$ compared with baseline at 6 -month and 12-month follow-up in first and second patient. Third patient was not considered echocardiographic responder (no reduction in LV volume). First and second patient improved $>10 \%$ the distance covered in the 6 -minute walking test at follow-up. Positive clinical response was absent in third patient. At 6-month and 12-month MR was 2 and $3+$ respectively in third patient. No MR recurrence was observed in remaining patients.

\section{Conclusions}

CRT in patients with no residual MR yields improved reverse remodeling, response to resynchronization, functional status and survival (clinical and ECHO responders).

\footnotetext{
* Correspondence: sborovic2001@yahoo.com

Dedinje Cardiovascular Institute, Belgrade, Serbia
}

Concomitant mitral valve repair and resynchronization therapy is feasible, safe, with acceptable results.

Published: 11 September 2013

doi:10.1186/1749-8090-8-S1-0271

Cite this article as: Borovic et al:: Concomitant mitral valve repair and resynchronization therapy. Journal of Cardiothoracic Surgery 2013

8(Suppl 1):0271.
Submit your next manuscript to BioMed Central and take full advantage of:

- Convenient online submission

- Thorough peer review

- No space constraints or color figure charges

- Immediate publication on acceptance

- Inclusion in PubMed, CAS, Scopus and Google Scholar

- Research which is freely available for redistribution
C Biomed Central
C Biomed Central

(C) 2013 Borovic et al; licensee BioMed Central Ltd. This is an Open Access article distributed under the terms of the Creative Commons Attribution License (http://creativecommons.org/licenses/by/2.0), which permits unrestricted use, distribution, and reproduction in any medium, provided the original work is properly cited. 